\title{
Фондирование документов на старомонгольской письменности Национального архива Республики Тыва: история и проблемы совершенствования
}

\author{
Аяна А. Самдан \\ Тувинский институт гуманитарных и прикладных социально-экономических исследований \\ при Правительстве Республики Тыва, Российская Федерация
}

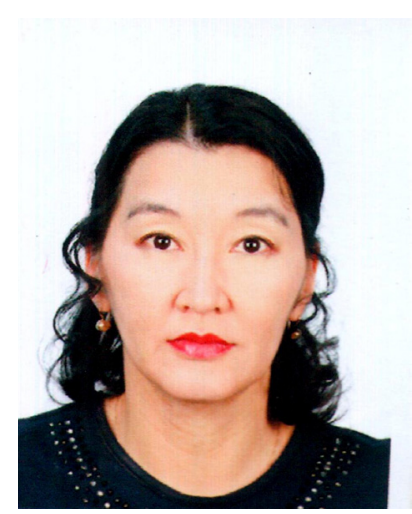

В статье воссоздается история фондирования документного массива Национального (до 07.04.2020 г. - Государственного) архива Республики Тыва на старомонгольском письменном языке. В качестве объекта исследования выбран монгольский фонд № 115, так как из данного фонда в дальнейшем были сформированы все другие фонды, содержащие монгольские документы. Он включает довольно обширный период: цинский (начало XVIII в. 1912 г.), промежуток времени под российским протекторатом (1914-1921 г2.) и первое десятилетие Тувинской Народной Республики (1921-1933 г2.). Все документы написаны на старомонгольском письменном языке.

История фонда неразрывно связана с историей самого архива. Сначала документы формировались по хронологическим, отраслевым и тематическим принципам, сохранялось традиционное документоведение по хронологии, часть из документов переводилась на тувинский язык. В советское время организация архивного дела строилась по правилам архивного дела СССР. Возросло количество архивных материалов. Основной проблемой стало отсутствие квалифицированных специалистов со знанием старописьменного монгольского языка и истории Тувы. Происходили передвижения документов по фондам. Значителен вклад в изучение монгольского фонда бурятского ученого П. Б. Балданжапова (1957 г.).

Материалы фонда активно стали исследоваться и использоваться в 2011-2014 г2. в рамках научного сотрудничества архива с Тувинским институтом гуманитарных и прикладных социально-экономических исследований. В 2011-2014 г2. были опубликованы 4 тома «Собраний архивных документов по истории Тувы».

В настоящее время продолжается работа по совершенствованию 115-го фонда. Планируется создание электронного каталога, оцифровка документов, реставрация и пр.

Ключевые слова: Тува; архив; Государственный архив Республики Тыва; Национальный архив Республики Тыва; старомонгольская письменность; монгольский язык; архивный документ; оцифровка

\section{Для цитирования:}

Самдан А. А. Фондирование документов на старомонгольской письменности Национального архива Республики Тыва: история и проблемы совершенствования // Новые исследования Тувы. 2020, № 2. C. 137-144. DOI: https:// www.doi.org/10.25178/nit.2020.2.9

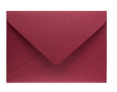

Самдан Аяна Анай-ооловна - кандидат исторических наук, ведущий научный сотрудник группы истории Тувинского института гуманитарных и прикладных социально-экономических исследований. Адрес: 667000, Россия, г. Кызыл, ул. Кочетова, д. 4. Тел: +7 (39422) 2-39-36. Эл. адрес: camayana@mail.ru

ORCID ID: 0000-0002-7785-7497

Samdan Ayana Anai-oolovna, Candidate of History, Leading Research Fellow, Group of History, Tuvan Institute for the Humanities and Applied Socioeconomic Studies at the Government of Ministers of the Republic of Tuva. Postal address: 4 Kochetov St., 667000 Kyzyl, Russian Federation. Tel.: +7 (39422) 2-39-36. Email: camayana@mail.ru 


\title{
Managing the documents in Old Mongol writing at the National Archives of the Republic of Tuva: history and issues of improvement
}

\author{
Ayana A. Samdan \\ Tuvan Institute for the Humanities and Applied Socioeconomic Studies \\ at the Government of Ministers of the Republic of Tuva, Russian Federation
}

The article traces the history of managing the massive of documents in Old Mongolian writing preserved at the National Archives (prior to 07.04.2020 known as the State Archives) of the Republic of Tuva. We focus on Mongol fond No. 115, since all other fonds which contain Mongolian documents later split away from this collection. The fond covers documents created over a large span of time: the Qing period (early 18th century to 1912), the short period of the Russian protectorate (1914-1921) and the first decade of the Tuvan People's Republic (1921-1933). All of the documents are in Old Mongolian language.

The history of the fond is part and parcel of the history of the archive itself. Originally, the documents were grouped together by their chronological, thematic and subject matter features. Traditional chronological record keeping was accompanied by having some of the documents translated into Tuvan. In the Soviet years, archival work followed the common USSR guidelines. While the amount of archival material grew, there was an obvious lack of well-trained specialists who both knew Tuvan history and could read Old Mongolian writing. Documents have been moved between fonds. A significant contribution to studying the Mongolian fond was made by Buryat scholar P.B. Baldanzhapov (born 1957).

Materials preserved in the fond were actively studied and used in 2011-2014 when the Archives did a joint project with Tuvan Institute for the Humanities and Applied Socioeconomic Studies. 4 volumes of "A collection of archival documents on the history of Tuva" were published between 2011 and 2014.

At the moment, Fond 115 is still being improved, with an electronic catalogue to be set up. Other plans include digitizing and restoring the documents.

Keywords: Tuva; archive; State Archives of the Republic if Tuva; National Archives of the Republic of Tuva; Old Mongolian writing; Mongolian language; archival document; digitization

\section{For citation:}

Samdan A. A. Managing the documents in Old Mongol writing at the National Archives of the Republic of Tuva: history and issues of improvement. The New Research of Tuva, 2020; 2: 137-144. (In Russ.). DOI: https://www.doi.org/10.25178/ nit.2020.2.9

\section{Введение}

Документы на старомонгольском письменном языке, хранящиеся в Национальном архиве Республики Тыва (Государственном архиве Республики Тыва, ГА РТ) ${ }^{1}$ можно разделить на три группы:

1) документный массив периодов цинской империи (нач. XVIII в. - 1912 г.), российского протектората (1914-1921 гг.) и Тувинской Народной Республики (1921-1944 гг.) (далее - ТНР) - ФР-115 «Управление амбын-нойона Танну-Урянхая (Тувы) (1715-1930 гг.». Данный фонд в основном, за исключением переводов, состоит из документов на старомонгольской письменности, поэтому условно назовем его монгольским;

2) документы периода Тувы под российским протекторатом - ФР-112 «Управление комиссара по делам Урянхайского края» и ФР-123 «Управление заведующего устройством русского населения в Урянхайском крае». Имеются письма тувинских нойонов, адресованные русским административным властям по различным вопросам;

3) документы периода ТНР (ФП-1 «ЦК ТНРП²»; ФР-92 «Совет Министров ТНР 1921-1944»; ФР-93 «Президиум Малого Хурала ТНР»; ФР-99 «Министерство юстиции ТНР. 1922-1933 гг.»; ФР-100 «Ми-

\footnotetext{
${ }^{1}$ В связи с тем, что переименование архива пришлось на период предпечатной подготовки статьи (7 апреля 2020 г.) далее мы сохраняем в тексте старое название "Государственный архив Республики Тыва" и аббревиатуру "ГА РТ". - peд.

Editors' note: Since the Archives was renamed while editorial work on the article was already under way (April 7, 2020), we have preserved at some places the institution's old name - "State Archives of the Republic of Tuva".

${ }^{2}$ ТНРП - Тувинская Народно-революционная партия.
} 
нистерство иностранных дел ТНР. 1922-1944 гг.»; ФР-144, оп. 9 «Министерство внутренних дел ТНР. 1922-1932 гг.»; оп. 12-16 «Хошунные управления. 1921-1933 гг.» и др.). Документы на монгольском, русском и тувинском языках (на латинской основе и кириллице).

Такая разобщенность связана не только с тематическим формированием фондов, но и выделением в начале 1960-х гг. партийного архива, куда также попали документы на монгольском языке. Таким образом, последние в ГА РТ представлены в широком пласте и это связано с распространением и функционированием старомонгольской письменности в территории Тувы ${ }^{1}$.

Целью данной работы является воссоздание истории фондирования документного массива архива на старомонгольском письменном языке. В качестве объекта исследования нами был выбран монгольский фонд № 115, поскольку, как нам представляется, из данного фонда в дальнейшем были сформированы все другие фонды, содержащие монгольские документы. Исходя из нее формулировались следующие задачи, стоявшие перед автором: исследовать историю становления и дальнейшего фондирования 115-го фонда (с выделением периодизации); изучить современное состояние фонда с тем, чтобы оценить факторы степени полноты и сохранности фонда; определить дальнейшие действия по совершенствованию рассматриваемого нами фонда и оценить степени риска при выполнении архивных работ.

Важной группой источников для освещения истории фондирования 115-го фонда выступают: исторические справки к фондам, дела и листы 115 и 144 фондов, опись дел 115-го фонда. Также работа основана на архивных материалах 12 и 246 фондов ГА РТ.

\section{Из истории фондообразования № 115 фонда ГА РТ}

Фондообразование № 115 фонда неразрывно связана с историей самого архива. В 1943 г. в рамках акции сдачи документов организациями и учреждениями ТНР в архив, краеведческий музей республики сдал документы на старомонгольском письменном языке - всего 123 папок и еще «необработанные материалы на монгольском и тувинском языках в двух больших шкафах» (ГА РТ, ф. 92, оп. 1, д. 1185, л. 27). Впоследствии, в результате кропотливой работы архивистов, из них были сформированы 154 архивных томов, которые были обозначены как «История Тувы». Инвентаризационный список этих томов был составлен завоблархивом Кончуком 15 октября 1945 г. на тувинском языке.

Согласно данного списка, сюда вошли документы периодов Цинской империи (например, материалы восстания тувинского народа против китайских империалистов 1910-1913 гг.); российского протектората (например, материалы по вопросу правления Тувы русскими, монгольскими и тувинскими феодалами 1913-1920 г., прошение Буян-Бадыргы «русскому Белому царю» 1913 г.); военной интервенции (например, материалы о монгольских, китайских и русских войсках 1913-1920 гг. и ТНР 1921-1944 гг.; летописного характера («Краткая родословная правителей 5 хошунов Танну-Урянхая» 1859 г.; «Краткая родословная амбын-[нойонов] Танну-Урянхая» 1892 г.; «Краткая история Тувы» 1925 г. $^{2}$ ).

Остальная часть относится к периоду ТНР. Это, в основном, постановления Великих хуралов, делопроизводственные документы Совета Министров, разных министерств и ведомств, законодательные акты, соглашения, договора, материалы по Хемчикскому мятежу (Сувунак самыынының дугайында 1924 г.), политическим репрессиям (Танчайларның бөлүүн чылча шапкан дугайы 1938 г.), о тувинцахдобровольцах 1943 г. и др. (ГА РТ, ф. 246, оп. 1, д. 5, л. 31).

Из рассматриваемого инвентарного списка видно, что документы формировались по хронологическим, отраслевым и тематическим принципам. При этом также можно заметить, что сохранилось традиционное документоведение по хронологии - по годам правления маньчжурских императоров (напр., материалы периода правления Чжа-Чина и До-гуана 1818 г., материалы периода правления Гуан-Шуна 1874 г.). Здесь указаны даты, из скольких томов или частей состоит дело, а также язык написанных документов. При этом часть из них написана на тувинском языке, видимо, уже тогда привлекались переводчики. Известными переводчиками были Шагдыржап Иргит, Седип-оол Танов, Иргит Бадраа, Оюн Лундуп, Доткан (Ховалыг) и др.

${ }^{1}$ О распространении и функционировании монгольского языка на территории Тувы писали Б. И. Татаринцев в книге «Монгольское языковое влияние на тувинскую лексику» (Татаринцев, 1976), А. А. Самдан «Тувинские монголоязычные летописи» (Самдан, 2016) и др.

${ }^{2}$ Некоторые документы по названию сложно определить к какой категории их относить, напр.: «Эрги тоолчу номнар» - «Книги старых сказок - фольклор?», «Тыва 9 кожуун деп чүл» - «Что значит 9 хошунов Тувы». 


\section{Состояние фонда в середине 1940-1950-х годов}

После вхождения ТНР в состав СССР в 1944 г., организация архивного дела шло по советским основам. Благодаря налаживанию работы на должном уровне значительно возросло количество архивных материалов, но в то же время постепенно утрачивались традиции архивоведения дореволюционной Тувы.

В 1946-1947 гг. в результате кропотливой работы архивистов были сформированы 32 фонда, включающих 2604 единиц хранения. Фонды не были пронумерованы, а только имели наименования. Интересуемые нами дела были сконцентрированы в фонде «Шестьдесят тувинских революционеров», который состоял из 72 дел. Скорее всего, что в данный фонд вошли часть дел из инвентаризационного списка из 154 томов, касающихся периодов Цинской империи, российского протектората и иностранной военной интервенции в Туве.

Основная проблема при фондировании документов на старомонгольском языке - это, конечно, отсутствие квалифицированных специалистов со знанием старописьменного монгольского языка и истории Тувы.

В начале 1950-х гг. были сформированы 2 новых фонда, дела которых были изъяты из других фондов как не относящиеся к составу фонда:

Ф-26 «Правитель Урянхайского края князь кунь-найон» ${ }^{1}$, включающий 1 единицу хранения, датируемой 1921 г. - всего 3 л.,

Ф-27 «Управляющий Да хошуном (Кемчикским) Урянхайского края (1896-1917 гг.)», состоящий из 19 дел $^{2}$. Самый ранний документ датируется 1896 г., а поздний - 1921 г. В описи помимо заголовка единицы хранения имеются даты и количество листов. Все документы также небольшого объема от 1 л. до 14 л.

Продолжилась работа по систематизации, обработке документов и во второй половине 1950-х гг. Судя по учетным документам архива, произошло переформирование документного массива и многие документы на монгольском языке попали в № 144-й фонд.

В июле 1955 г. на основании указания Главного Архивного Управления МВД СССР, из фонда Ф-27 дела 14-19 были изъяты и переданы в вновь образованный № 115-й фонд. Название обоих фондов оставили прежними «Управляющий Да (Кемчикским) хошуном Урянхайского края». Но уже в следующем, 1956 г., по устному указанию начальника I отдела Архивного управления МВД РСФСР Коленкиной, эти два фонда были объединены (ГА РТ, дело фонда 115, л. 19).

Для оценки монгольского фонда архивисты привлекли бурятского ученого П. Б. Балданжапова, который в 1956-1957 гг. работал заместителем директора Кызылского пединститута. За этот короткий срок он смог также изучить монгольские фонды Тувинского научно-исследовательского института языка, литературы и истории (ТНИИЯЛИ) и краеведческого музея им. Алдан-Маадыр.

В Тувинском областном государственном архиве он работал с января по март 1957 г. В результате он разделил фонд на два периода:

- документы дореволюционной Тувы с 1740 до 1921 г.,

- материалы и документы периода республики 1921-1940-е годы (ГА РТ, дело фонда 115, л. 21).

Как правильно бурятский ученый заметил: «Дореволюционное собрание документов Госархива представляет в основном архив двух хемчикских хошунов ${ }^{3}$....Однако, необработанность этих материалов, отсутствие описания и характеристик некоторых документов затрудняют использование их в качестве исторических источников» (ГА РТ, дело фонда № 115, л. 23). Впоследствии, работая в г. Чите,

\footnotetext{
${ }^{1}$ Другое название «Канцелярия правителя Таа хошуна Урянхайской провинции Дацинского государства» (ГА РТ, дело фонда 115, л. 1-2).

2 Также имеется другая опись этого фонда с названием «Канцелярия правителя Таа хошуна Урянхайской провинции Дайцинского государства» - всего 10 единиц хранения.

${ }^{3}$ Об уничтожении архива амбын-нойона, главного правителя дореволюционной Тувы, писал М. С. Байыр-оол (Байыр-оол, 2009). По его версии, документы канцелярии амбын-нойона, упакованный и груженный на двух верблюдах, доставлялся в Кызыл. Около с. Верхне-Никольска (ныне - с. Бай-Хаак) перевозчики были остановлены неким красноармейцем, который распорядился сжечь их. Из Кызыла были присланы офицер и член Правительства ТНР Оюн Данчай. Последний «пытался их убедить не сжигать бумаги, запечатлевшие историю народа, но красноармейцы были непреклонны» (там же: 89). Так был уничтожен весь документный массив правителей Тувы - амбын-нойонов почти за двухсотлетнюю историю.
} 
П. Б. Балданжапов через архивный отдел УВД Читинского облисполкома, заказывал дела из Тувинского областного архива на временное пользование, чтобы закончить свою статью «Тува под гнетом маньчжурских захватчиков»1.

В 1957 г. 61 единица хранения была передана из 144-го фонда и составлена отдельная опись. Таким образом, фонд имел две описи: № 1 «Сообщения Усинского окружного начальника» (по первому названию документа) $)^{2}-19$ единиц хранения и № 2 «Переписка амбын-нойона с правителями хошунов за 1896-1921 гг.»3 - 61 дело и всего состоял из 80 дел. В последней описи половина из них, точнее 31 единица хранения не имела наименования и просто обозначена как «Документы». Дела в большинстве своем, судя по указанным страницам, объемные, в среднем около 350 страниц. Таким образом, на данном этапе основным фондообразователем стали внутренние ресурсы - фонды 27 и 144.

Можно предположить, что по идее вновь созданный 115-й фонд должен был включать документы только цинского периода Тувы (начало XVIII в. - 1912 г.) или хотя бы до 1921 г. Но в 1958 г. в этот фонд были добавлены 67 единиц хранения, датируемые 1921-1934 гг. В описи они названы как «Документы».

В описи от 1960 г. уже 275 единиц хранения обозначены тоже как «Документы на монгольском языке». Большая часть из них объемные, указаны даже 1497 листов.

В 1961 г. по распоряжению архивного отдела МВД Тувинского облисполкома 573 единиц хранения на монгольском языке из этого фонда были переданы по акту партийному архиву Тувинского обкома КПСС.

Таким образом, в рассматриваемый период шла активная работа по обработке архивных документов 115-го фонда, что значительно увеличило количество единиц хранения, но в то же время проблемы оставались прежними, и главная из них - нехватка специалистов со знанием старомонгольского письменного языка. Данное обстоятельство во многом не позволяло качественно обработать документный массив.

\section{Обработка и систематизация № 115-го фонда в 1960-1980-е годы}

Работа по систематизации документов и переводов не останавливалась. Во второй половине 1960-х гг. фонд был переименован в «Амбын-нойоны и правители хошунов Тувы», а уже в 1970-е годы - «Управление нойонов Танну-Урянхая (Тувы)». Если в 1974 г. насчитывались 209 единиц хранения, то к концу 1981 г. - 334. Это было связано не с поступлением новых дел, как это может показаться на первый взгляд, а скорее всего, с научно-технической обработкой тех объемных документов, которые ранее именовались просто как «Документы».

В 1980-е годы практически остановилась работа по переработке документов, поскольку весь внутренний резерв был исчерпан, а поступление новых не зафиксировано. Основные усилия были направлены на их перевод, так как было острая необходимость в использовании архивных документов для научных изысканий. Переводы, в основном, осуществлялись на тувинский язык, на русский же их значительно меньше. Это связано, прежде всего, с квалификацией переводчиков. Но все аннотации к документам составлялись на русском языке. Переводчиками в рассматриваемое время были К.Д. Аракчаа, прекрасный знаток монгольской письменности, выпускники Монгольского государственного университета Б. С. Сонам, К. А. Бичелдей, А. Э.-Г. Уланова и др. В большинстве случаев переводы приклеивались к документу, но в фонде имеются несколько дел, сформированные из одних переводов. Но поскольку не указаны номера дел и листы, то данное обстоятельство несколько затрудняет идентификацию их с оригиналом.

Одной из задач архивов в советское время была научно-исследовательская, культурно-просветительская и агитационно-пропагандистская работа, в которой широко использовались архивные документы. На основе выявленных архивных документов были написаны статьи, которые печатались в республиканских газетах, читали лекции, которые использовались в радио и телепередачах, во время проведений экскурсий, семинаров, составлены тематические обзоры документов по различным темам, что существенно облегчала поисковую работу исследователям. Кроме того, тувинскими архивистами были подготовлены материалы по использованию документальных материалов в научных целях как по отдельным темам (например, «Материалы о восстании 60-ти богатырей, 1883-1885» (ГА РТ, ф. 12,

${ }^{1}$ Подробно о статье П. Б. Балданжапова можно прочитать в работе В. А. Василенко (Василенко, 2012).

${ }^{2}$ В 1957 г. опись называлась «Сообщения, циркуляры, отношения» (1896-1921 гг.).

${ }^{3}$ В 1959 г. данная опись называлась «Документы на монгольском языке. 1757-1921 гг.». 
оп. 1, д. 44), так и обобщающего характера (например, История Тувы (ГА РТ, ф. 12, оп. 1, д. 102, 103), где были использованы переводы со старомонгольского языка.

Также в конце 1980-х годов была начата работа по составлению хрестоматии по истории Тувы, который должен был состоять из двух томов (1 том охватывал период с 1759 по 1921 гг., 2-й том, можно предположить - с 1921 - по совр. время). На сегодняшний день мы можем сказать, что данная работа не завершена.

\section{Современное состояние № 115-го фонда}

В 2011-2014 гг. ГА РТ в рамках научного сотрудничества с Тувинским институтом гуманитарных и прикладных социально-экономических исследований (ТИГПИ, бывший ТНИИЯЛИ) и Институтом истории Академии наук Монголии принял участие в публикации архивных документов. В свет вышло 4 тома «Собрания архивных документов по истории Тувы»: в I том (1738-1911 гг.) - вошли 189 документов, из них более 70\% из ГА РТ (Тувгийн туухэнд ..., 2011a); II том (1911-1921 гг.) - включены 125 документов (Тувагийн туухэнд ..., 2011b), III том (1921-1944 гг.) - 110 документов, из них 11 - на русском и 8 - на тувинском языках (Тувагийн туухэнд ..., 2014а) и IV том (1944-1991 гг.) - 67 документов, из них всего 3 - на старомонгольской письменности (Тувагийн туухэнд ..., 2014b).

115-й фонд включает довольно обширный период: цинский (начало XVIII в. - 1912 г.), промежуток времени под российским протекторатом (1914-1921 гг.) и первое десятилетие Тувинской Народной Республики (1921-1933 гг.). Пожалуй, их всех объединяет только то, что все документы написаны на старомонгольском письменном языке.

Имеется все основные учетные документы фонда: историческая справка, дело фонда, опись дел. Всего имеется 340 единиц хранения. Внутри описи они систематизированы по тематике на хозяйственные, судебные, административные, исторические, а также по правлениям нойонов Хемчикского хошуна (Очура, Бызыя, Базыра, Дугара (Дугера), Сарая, Хайдыпа, Буян-Бадыргы). В большинстве своем это делопроизводственные документы (письма, протоколы, отношения, приказы и т. д.) из канцелярий двух хемчикских хошунов, поэтому название фонда, как нам представляется, необходимо привести в соответствие с содержанием фонда.

Документы цинского периода написаны в большинстве своем на китайской тонкой бумаге, и они все разноформатны. Имеются многостраничные тетради, прошитые шнуром из кожи и кожаном переплете, многометровые рукописные свитки. В советское время из свитков, длина которых могла достичь до трех метров, были сформированы документы формата А4 (беспорядочно загнуты под его размеры) и прошиты и даже приклеены в дела, т. е. никак не учитывалась традиция архивоведения дореволюционной Тувы. Свитки были загнуты и в местах сгибов записи затерлись, вся бумага скомкалась, помялась. Переводчики делали записи прямо на документах шариковыми ручками или химическими карандашами, а архивные работники на них же клеили переводы или аннотации, вследствие чего канцелярский клей, деформируя бумагу, оставлял желтые пятна, въедался в структуру бумаги. Также один и тот же документ многократно пронумеровывался. Все это привело с течением времени к ухудшению физического состояние документов.

\section{Совериенствование 115-го фонда}

В настоящее время продолжается работа по совершенствованию 115-го фонда. К ней относится создание электронного каталога, который позволит осуществить подокументальную каталогизацию дела, где к каждому документу должны быть составлены перевод заголовка, краткая аннотация, датировка, авторство (если есть об этом сведения). Это поможет установить точное количество имеющихся документов в данном фонде. Затем нужно провести систематизацию по их тематическому и хронологическому признаку. Это, естественно, потребует почти полной переработки всего фонда. При этом нужно сохранить традиции ведения делопроизводственных документов как в дореволюционной Туве, а именно составить опись по правлению того или иного правителя хошуна, в нашем случае Хемчикского хошуна (хронологический принцип), внутри же разделить их по темам (административные, хозяйственные, судебные). Здесь нужно провести филигранную работу, чтобы сохранить старый номер дела и страницы документа.

Параллельно с созданием электронной базы будет проводиться и оцифровка документов с высоким разрешением с целью создания страхового фонда архивных документов. Электронная база позволит 
не только существенно ускорить процесс поиска, но в дальнейшем составить и электронно-тематические коллекции на базе архивных документов.

При переводе архивных документов на электронный формат (оцифровки) они будут переведены в единый графический формат ${ }^{1}$, поэтому необходимо параллельно делать своего рода паспорт документа, где будут указаны размер и описание бумаги, использованные материалы (краска, инструменты для письма), количество строк и др.

Большинство документов данного фонда нуждается в реставрации. В настоящее время остро стоит необходимость создания лаборатории по реставрации документов. Это потребует материальных средств для покупки необходимого оборудования и расходных материалов, нужны специалисты-реставраторы, обученные работать с китайской тонкой бумагой. В апреле 2019 г. два сотрудника архива Т. Е. Котюшева и А. Д.-С. Куулар прошли курсы повышения квалификации в Научной библиотеке Томского государственного университета. В дальнейшем необходимо продолжать столь нужную работу.

Мы рекомендуем, чтобы каждый документ после проведенной реставрации хранился в отдельной папке или конверте, т. е. в формате 1 документ - 1 дело. В папке будут даны название, краткая аннотация на русском языке и паспорт документа.

Кроме того, нужно провести интеграцию некоторых документов из бывших фондов Центра архивных документов партийных и общественных организаций (ЦАДПОО), поскольку они по всем параметрам (исторический период, язык, тематика) должны быть в 115-м фонде и в то же время передать документы ТНР в соответствующий фонд.

Не потерял своей остроты и вопрос перевода документов на тувинский и русский языки.

\section{Заключение}

В силу исторических и геополитических условий с момента вхождения в состав Цинской империи (в начале XVII в.) и до официального введения тувинской национальной письменности (1930 г.) тувинцы пользовались монгольским письмом. Об этом свидетельствуют многотомные рукописные памятники, манускрипты, буддийские сутры на старомонгольском письменном языке, сохранившие в ГА РТ, архивах Национального музея Республики Тыва и ТИГПИ. Систематизация, каталогизация собраний, коллекций, корпуса документов на монгольском языке по различным темам (исторические, буддийские, шаманские и др.), без сомнения, позволит обобщить историко-документальное наследие, которым обладает тувинский народ, а также значительно расширит источниковую базу научных исследований.

Поэтому в настоящее время необходимо предпринимать все меры по его поддержке, а каталогизация, паспортизация архивных документов является составной частью сохранения данного наследия.

Как уже выше подчеркивалось, фондообразованием монгольского фонда в большинстве своем послужили материалы двух хемчикских хошунов, что, конечно же, не отражает почти двухсотлетнюю историю Тувы в составе Цинской империи. Поэтому необходимо, на наш взгляд, продолжить целенаправленную работу среди населения республики по выявлению рукописей на старомонгольской письменности, возможно, еще хранящихся в частных коллекциях, пещерах или же тайниках, организовывая археографические экспедиции, конкурсы и др. мероприятия. Кроме того, нужно вести поисковую работу документов, в том числе и на старомонгольской письменности, касающихся истории тувинского народа в собраниях российских и зарубежных архивов и библиотек. В перспективе, возможно, есть необходимость создать единую электронную базу данных документного массива по истории Тувы на старомонгольском языке фондов ГА РТ, Национального музея Республики Тыва и ТИГПИ. Для этого необходима совместная работа ученых, архивистов и музейных работников.

\footnotetext{
${ }^{1}$ При сканировании документов встанет вопрос, в каком формате сохранять изображения - в расширенном или сжатом (TIFF или JPEG). Несомненно, формат JPEG наиболее экономичный и позволяет при сканировании и сохранении файла не тратить значительное время. Мы работаем с рукописным текстом, порой написанным неумелым почерком, иногда с множественными орфографическими ошибками, и чтобы разобраться в нем нужно будет существенно увеличивать, детализировать изображение, а данное действие без ущерба качества в мегопикселях возможно в формате TIFF.
} 


\section{СПИСОК ЛИТЕРАТУРЫ}

Байыр-оол, М. (2009) Политический портрет М. Буян-Бадыргы // Монгуш Буян-Бадыргы - основатель тувинской государственности. Материалы республиканской научно-практической конференции, посвященной 115-летию со дня рождения Монгуша Буян-Бадыргы / ред. и сост. У. П. Бичелдей. Кызыл : Тываполиграф. 194 с. С. $88-141$.

Василенко, В. А. (2012) Неопубликованная рукопись Пурбо Балданжапова «Тува под гнетом маньчжурских захватчиков» [Электронный ресурс] // Новые исследования Тувы. № 2. URL: https://nit.tuva.asia/nit/article/view/335 (дата обращения: 01.02.2020).

Самдан, А. А. (2016) Тувинские монголоязычные летописи. Абакан : Журналист. 185 с.

Тувагийн туухэнд холбогдох архивын баримдын эмхэтгэл. Боть I (1738-1911) = Собрание архивных документов по истории Тувы. Том I (1738-1911) = Тыванын тоогузунге хамааржыр шыгжамырлар бижимелдеринин чыындызы. 1-ги том (1738-1911) (2011а) / гл. ред. С. Чулуун, А. К. Бичелдей. Уланбаатар ; Кызыл : б. и. 498 с. (На монг., рус. и тув. яз.).

Тувагийн туухэнд холбогдох архивын баримдын эмхэтгэл. Боть II (1911-1921) = Собрание архивных документов по истории Тувы. Том II (1911-1921) = Тыванын тоогузунге хамааржыр шыгжамырлар бижимелдеринин чыындызы. 2-ги том (1911-1921) (2011b) / гл. ред. С. Чулуун, А. К. Бичелдей. Уланбаатар ; Кызыл : б. и. 469 с. (На монг., рус. и тув. яз.).

Тувагийн туухэнд холбогдох архивын баримдын эмхэтгэл. Боть III (1921-1944) = Собрание архивных документов по истории Тувы. Том III (1921-1944) = Тыванын тоогузунге хамааржыр шыгжамырлар бижимелдеринин чыындызы. Том III (1921-1944) (2014а) / гл. ред. С. Чулуун, А. К. Бичелдей. Уланбаатар ; Кызыл : б. и. 418 с. (На монг., рус. и тув. яз.).

Тувагийн туухэнд холбогдох архивын баримдын эмхэтгэл. Боть IV. Собрание архивных документов по истории Тувы. Toм IV (1944-1991). Тыванын тоогузунге хамааржыр шыгжамырлар бижимелдеринин чыындызы. Tом IV (1944-1991) (2014b) / гл. ред. С. Чулуун, А. К. Бичелдей. Уланбаатар ; Кызыл : б. и. 166 с. (На монг., рус. и тув. яз.).

Татаринцев, Б. И. (1976) Монгольское языковое влияние на тувинскую лексику. Кызыл : Тувин. кн. изд-во. 130 с. Дата поступления: 01.03.2020 г.

\section{REFERENCES}

Baiyr-ool, M. (2009) Politicheskii portret M. Buian-Badyrgy [Political portrait of M. Buyan-Badyrgy]. In: Mongush BuianBadyrgy - osnovatel' tuvinskoi gosudarstvennosti [Mongush Buyan-Badyrgy as the founder of Tuva statehood]. Materials of the Republican scientific and practical conference dedicated to the 115th anniversary of the birth of Mongush Buyan-Badyrgy / ed. and comp. by U. P. Bicheldei. Kyzyl, Tyvapoligraf. 194 p. Pp. 88-141. (In Russ.).

Vasilenko, V. A. (2012) Neopublikovannaia rukopis' Purbo Baldanzhapova «Tuva pod gnetom man'chzhurskikh zakhvatchikov» [Purbo Baldanzhapov's unpublished manuscript “Tuva under the yoke of the manchu invaders"]. The New Research of Tuva, no. 2 [online] Available at: https://nit.tuva.asia/nit/article/view/335 (access date: 01.02.2020).

Samdan, A. A. (2016) Tuvinskie mongoloiazychnye letopisi [Tuva Mongol-language Chronicles]. Abakan, Zhurnalist. 185 p. (In Russ.).

Tuvagiin tuukhend kholbogdokh arkhivyn barimdyn emkhetgel. Bot' I (1738-1911) = Sobranie arkhivnykh dokumentov po istorii Tuvy. Tom I (1738-1911) = Tyvanyn tooguzunge khamaarzhyr shygzhamyrlar bizhimelderinin chyyndyzy. 1-gi tom (1738-1911) [A collection of archival documents on the history of Tuva. Vol. 1. (1738-1911)] (2011a) / ed. by S. Chuluun and K. A. Bicheldei. Ulanbaatar; Kyzyl, s. n. 498 p. (In Mong., Russ. and Tuv.).

Tuvagiin tuukhend kholbogdokh arkhivyn barimdyn emkhetgel. Bot' II (1911-1921) = Sobranie arkhivnykh dokumentov po istorii Tuvy. Tom II (1911-1921) = Tyvanyn tooguzunge khamaarzhyr shygzhamyrlar bizhimelderinin chyyndyzy. 2-gi tom (1911-1921) [A collection of archival documents on the history of Tuva. Vol. 2 (1911-1921]. (2011b) / ed. by S. Chuluun and K. A. Bicheldei. Ulanbaatar; Kyzyl, s. n. 469 p. (In Mong., Russ. and Tuv.).

Tuvagiin tuukhend kholbogdokh arkhivyn barimdyn emkhetgel. Bot' III (1921-1944) = Sobranie arkhivnykh dokumentov po istorii Tuvy. Tom III (1921-1944) = Tyvanyn tooguzunge khamaarzhyr shygzhamyrlar bizhimelderinin chyyndyzy. Tom III (1921-1944) [A collection of archival documents on the history of Tuva. Vol. 3 (1921-1944] (2014a) / ed. by S. Chuluun and K. A. Bicheldei. Ulanbaatar; Kyzyl, s. n. 418 p. (In Mong., Russ. and Tuv.).

Tuvagiin tuukhend kholbogdokh arkhivyn barimdyn emkhetgel. Bot' IV. Sobranie arkhivnykh dokumentov po istorii Tuvy. Tom IV (1944-1991). Tyvanyn tooguzunge khamaarzhyr shygzhamyrlar bizhimelderinin chyyndyzy. Tom IV (1944-1991) [A collection of archival documents on the history of Tuva. Vol. 2 (1944-1991] (2014b) / ed. by S. Chuluun and K. A. Bicheldei. Ulanbaatar; Kyzyl, s. n. 166 p. (In Mong., Russ. and Tuv.).

Tatarincev, B. I. (1976) Mongol'skoe yazykovoe vliyanie na tuvinskuyu leksiku [Mongolian language influence on the Tuva lexicon]. Kyzyl, Tuvinskii nauchno-issledovatel'skii institut yazyka, literatury i istorii. 129 p. (In Russ.).

Submission date: 01.03.2020. 